\title{
Influence of resin content and pulping temperature on the formaldehyde release from medium density fibreboards (MDF)
}

\author{
E. Roffael
}

Received: 7 December 2011 / Published online: 17 May 2012

(C) The Author(s) 2012. This article is published with open access at Springerlink.com

\begin{abstract}
Increasing the binder content from $12 \%$ to $20 \%$ in medium density fibreboards (MDF) using a slightly melamine modified ( $3 \%$ melamine) UF-resin of a molar ratio $F: U$ of $1: 1$ causes a decrease in the formaldehyde release from the boards prepared under the same conditions. The formaldehyde emanation was measured using the perforator (EN120) and the flask method (EN 717-3) after a reaction period of $3 \mathrm{~h}$ and $24 \mathrm{~h}$. The results apply for boards made from thermo-mechanical pulps (TMP) prepared by pulping wood at $140{ }^{\circ} \mathrm{C}$ and $175^{\circ} \mathrm{C}$.

The pulping temperature of wood also impacts the formaldehyde release from MDF prepared therefrom. Ascending the pulping temperature from $140{ }^{\circ} \mathrm{C}$ to $175^{\circ} \mathrm{C}$ has a positive, but less significant influence on the formaldehyde release compared to that of increasing the binder content from $12 \%$ to $20 \%$. Insofar, it becomes evident from the results that the conclusions drawn in the literature pertaining to the influence of resin content in case of high molar ratio resins do not necessarily apply to low molar ratio resins.
\end{abstract}

\section{Einfluss des Bindemittelgehalts und \\ der Aufschlusstemperatur auf die Formaldehydabgabe von mitteldichten Faserplatten (MDF)}

Zusammenfassung Die Erhöhung des Gehalts an mit Melamin (3\%) modifiziertem UF-Harz mit dem Molverhältnis F:U 1:1 von $12 \%$ auf $20 \%$ in MDF führt unter sonst vergleichbaren Herstellungsbedingungen der MDF zu einer Verminderung der Formaldehydabgabe der hergestellten Platten, ermittelt nach dem Perforatorverfahren (EN 120)

E. Roffael $(\bowtie)$

Georg-August-Universität Göttingen, Büsgenweg 1,

Göttingen 37077, Germany

e-mail: eroffae1@gwdg.de und der Flaschenmethode (EN 717-3) nach einer Reaktionsdauer von $3 \mathrm{~h}$ und $24 \mathrm{~h}$. Die Anhebung der Aufschlusstemperatur von $140{ }^{\circ} \mathrm{C}$ auf $175{ }^{\circ} \mathrm{C}$ bei der Herstellung des thermo-mechanischen Holzstoffes (TMP) für die Plattenherstellung hat einen schwachen positiven Einfluss auf die Formaldehydabgabe, ermittelt nach den beiden oben erwähnten Verfahren. Dieser Effekt bleibt hinter dem der Erhöhung des Bindemittelgehalts von $12 \%$ auf $20 \%$ zurück. Insofern lassen die Ergebnisse deutlich werden, dass die in der Literatur veröffentlichten Ergebnisse bezüglich des Einflusses des Bindemittelaufwandes auf die Formaldehydabgabe im Falle von Harzen mit hohen Molverhältnissen (F:U) nicht zwangsläufig auf die der Harze mit sehr niedrigem Molverhältnis übertragbar sind.

\section{Introduction}

Urea formaldehyde resins (UF-resins) are the main binders used in the wood-based panels industry. Recently, increased awareness of ecology and clean indoor requirement boosted research activity to reduce the formaldehyde emanation from wood-based composites and resulted in the development of UF-resins of extremely low molar ratio (F:U) to be used as a bonding agent. To meet the tight specifications of different regulations enforced in several countries like $\mathrm{F}^{* * * *}$ in Japan (JIS A 1460 2001) UF-resins of molar ratio F:U 1:1 or even much less are used today as adhesives in the industry. Decreasing the molar ratio of formaldehyde to urea $(\mathrm{F}: \mathrm{U})$ below a certain limit leads, however, to a significant deterioration in the properties of the resin itself (low reactivity, lower moisture resistance) and in the physical-mechanical properties of the boards (high thickness swelling, low internal bond strength) bonded therewith (Sundin et al. 1987). To offset the negative impact of low 
Fig. 1 Influence of pulping temperature and resin content in MDF on the perforator value (corrected according to Jann and Deppe 1990)

Abb. 1 Einfluss der Aufschlusstemperatur des Holzes und des Bindemittelaufwandes in MDF auf den Perforatorwert (korrigiert nach Jann und Deppe 1990)

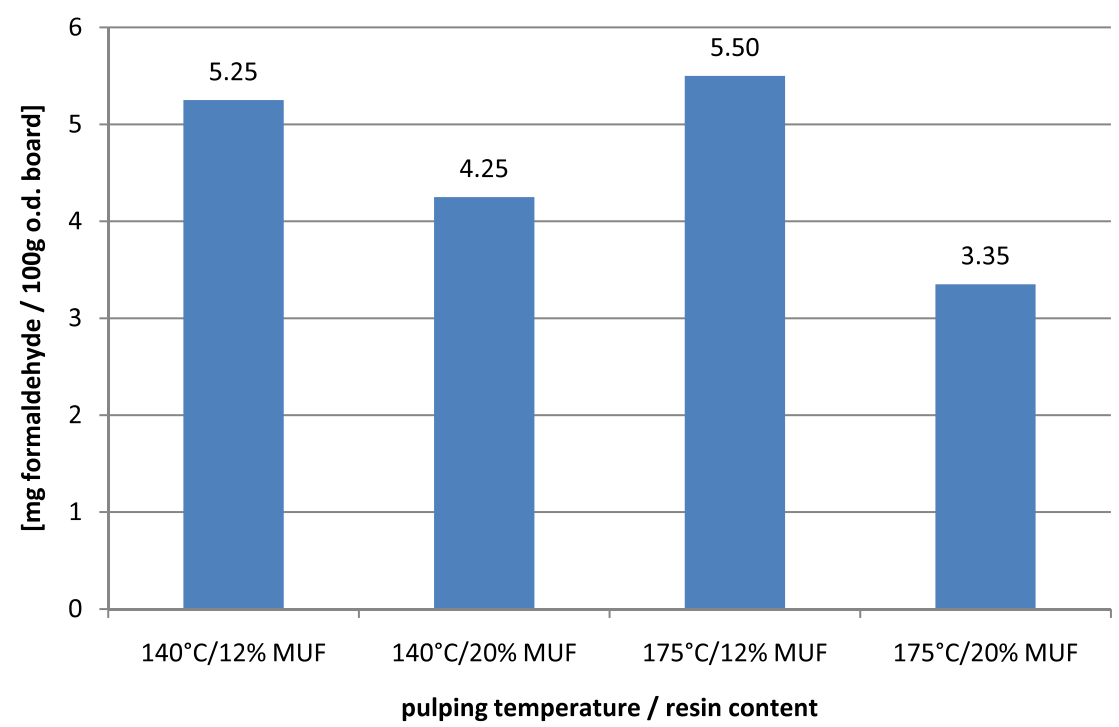

3 Results and discussion

molar ratio resins on the board properties, the level of resin loading in the boards is generally increased.

The influence of resin content in particleboards has been studied by Petersen et al. (1973) using resins of molar ratio between F:U 1.6 and 1.4. The results clearly indicate that by using high molar ratio resins of F:U 1.6:1 increasing the binder content between $5 \%$ and $12 \%$ leads to a remarkably higher perforator value; by using F:U resins of 1.4:1 the influence of resin level, however, was found to be too insignificant over the range of binder content between $5 \%$ and $12 \%$. Efforts were in vain to find literature systematically covering the influence of resin content on the formaldehyde release in particle- or fibreboards bonded with very low formaldehyde UF-resins of molar ratio F:U of 1:1 or lower.

\section{Experimental work}

The influence of resin content in medium density fibreboards (MDF) was evaluated on $16 \mathrm{~mm}$-boards with a density of $0.78 \mathrm{~g} / \mathrm{cm}^{3}$ made from thermo-mechanical pulps (TMP) prepared from beech wood at two different pulping temperatures $\left(140{ }^{\circ} \mathrm{C}\right.$ and $\left.175{ }^{\circ} \mathrm{C}\right)$ using two resin levels (12\% and $20 \%$ solids based on dry fibres). The boards were made using the blow-line technique with a UF-resin of molar ratio 1:1 containing about $3 \%$ melamine. No hardener was used to cure the resin. The pressing temperature was $190{ }^{\circ} \mathrm{C}$ and the pressing time was $24 \mathrm{~s} / \mathrm{mm}$. After conditioning for three weeks at $20{ }^{\circ} \mathrm{C}$ and $65 \%$ rel. humidity the formaldehyde release of the boards was assessed using the perforator technique (EN 120) and the flask method (EN 717-3) after a reaction time of $3 \mathrm{~h}$ and $24 \mathrm{~h}$. The measured perforator values were also corrected to a moisture content of $6.5 \%$ according to EN 312 using the empirical formula developed by Jann and Deppe (1990).
As can be seen from Fig. 1, the corrected perforator values decreased significantly by raising the resin level in the boards from $12 \%$ to $20 \%$. This applies to boards made from thermo-mechanical fibres (TMP) generated from wood at a pulping temperature of $140{ }^{\circ} \mathrm{C}$ and $175^{\circ} \mathrm{C}$.

The decrease in the perforator value was particularly pronounced in case of boards made from fibres prepared at a pulping temperature of $175{ }^{\circ} \mathrm{C}$. The perforator value decreased by about $28 \%$ by increasing the binder level from $12 \%$ to $20 \%$ in case of MDF made from TMP prepared at $140{ }^{\circ} \mathrm{C}$ and by more than $42 \%$ for boards made from TMP prepared at $175{ }^{\circ} \mathrm{C}$. As there are some uncertainties regarding the correction factor in case of boards with subtle differences in the perforator values in the low emission re(Johnsson et al. 2011). The same trend was also evident by comparing the measured but uncorrected perforator values (Fig. 2). The measured perforator values decreased slightly with increasing pulping temperature of the fibres at the same binder level of $12 \%$; the drop in the perforator value due to the increase in the pulping temperature is much more significant at a resin level of $20 \%$ in the boards. This may be due to the higher fibre acidity of thermo-mechanical pulps produced at $175^{\circ} \mathrm{C}$ (pH-value $\left.\sim 5.2\right)$ compared to that of fibres produced at $140{ }^{\circ} \mathrm{C}(\mathrm{pH}$-value $\sim 5.9)$ as lower $\mathrm{pH}$-values

Using the flask method (EN 717-3) for assessing the formaldehyde release after a reaction time of $3 \mathrm{~h}$ and $24 \mathrm{~h}$ leads to more or less the same results (Fig. 3). At a resin content of $20 \%$ in the boards lower values of formaldehyde release were measured compared to the values obtained for boards bonded with $12 \%$. This was especially distinctive gion the uncorrected perforator values were also measured enhance hardening of the resin. 
Fig. 2 Influence of pulping temperature and resin content in MDF on the uncorrected perforator value

Abb. 2 Einfluss der

Aufschlusstemperatur des Holzes und des Bindemittelaufwandes in MDF auf den Perforatorwert (unkorrigiert)
Fig. 3 Influence of pulping temperature and resin content in MDF on the formaldehyde release after $3 \mathrm{~h}$ and $24 \mathrm{~h}$ in the flask test, according to EN 717-3 Abb. 3 Einfluss der Aufschlusstemperatur des Holzes und des Bindemittelaufwandes in MDF auf die Formaldehydabgabe, ermittelt nach einer Lagerungsdauer von $3 \mathrm{~h}$ und $24 \mathrm{~h}$ im Flaschentest (EN 717-3)
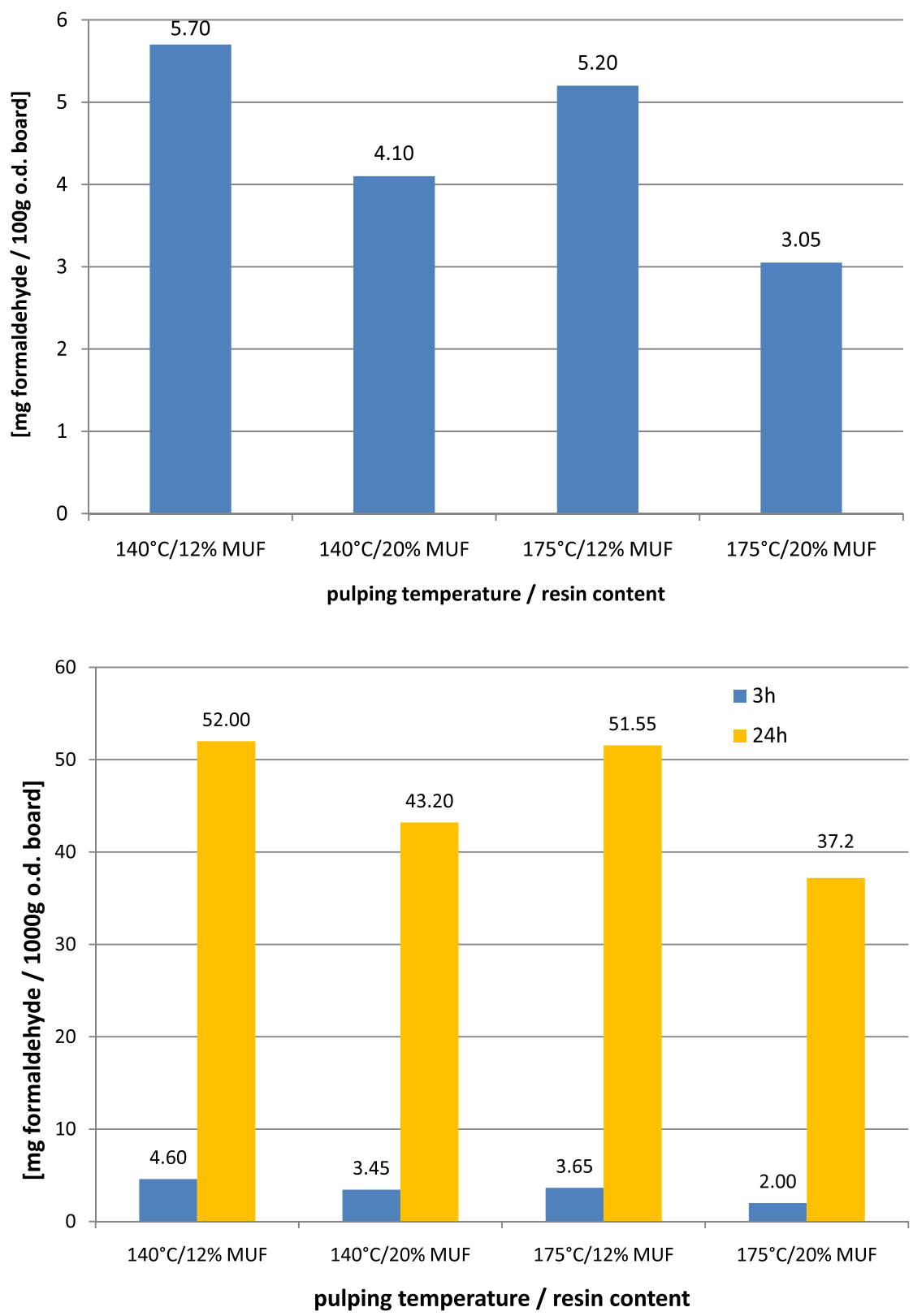

after a reaction period of $24 \mathrm{~h}$. Differences in the formaldehyde release were also registered between the boards made from TMP prepared by pulping wood at $175^{\circ} \mathrm{C}$ compared to those prepared from TMP obtained by wood pulping at $140^{\circ} \mathrm{C}$. However, the influence of resin content in the boards is much more pronounced than that of the pulping temperature.

\section{Conclusion}

The formaldehyde release of medium density fibreboards (MDF) bonded with low molar ratio $\left(\mathrm{F}: \mathrm{NH}_{2}\right)$ urea-formaldehyde resins (UF-resins) decreases significantly by increasing the binder content from $12 \%$ to $20 \%$. Increasing the pulping temperature of wood from $140{ }^{\circ} \mathrm{C}$ to $175^{\circ} \mathrm{C}$ reduces also the emanation of formaldehyde from the boards. The liberation of formaldehyde was measured by the flask method (EN 717-3) and the perforator technique (EN 120).

Open Access This article is distributed under the terms of the Creative Commons Attribution License which permits any use, distribution, and reproduction in any medium, provided the original author(s) and the source are credited.

\section{References}

JIS A 1460 (2001) Building boards determination of formaldehyde emission-desiccator method. Japanese Standards Association (JSA) 
Jann O, Deppe H-J (1990) Zur Berücksichtigung der Materialfeuchte bei der Formaldehydmessung von Spanplatten. Holz Roh- Werkst 48:365-368

Johnsson B, Engström B, Roffael E (2011) Influence of molar ratio in aminoplastic resins on the dependence of the measured perforator values on the moisture content of wood-based panels. Wood Sci Technol 45:389-398

Petersen H, Reuther W, Eisele W, Wittmann O (1973) Zur Formaldehydabspaltung bei der Spanplattenerzeugung mit Harnstoff-
Formaldehyd-Bindemitteln. 2. Mitteilung: Der Einfluss der Festharzmenge, Preßzeit und Preßtemperatur. Holz Roh- Werkst 31:463-469

Sundin B, Månsson B, Endrody E (1987) Particle boards with different contents of releasable formaldehyde: a comparison of the board properties including results from four different formaldehyde tests. Paper presented at 21st international symposium on particleboard/composite materials, Washington State University, Pullman, USA 